\title{
TFDP2 wt Allele
}

National Cancer Institute

\section{Source}

National Cancer Institute. TFDP2 wt Allele. NCI Thesaurus. Code C53109.

Human TFDP2 wild-type allele is located in the vicinity of 3q23 and is approximately 198 $\mathrm{kb}$ in leng th. This allele, which encodes transcription factor Dp-2 protein, is involved in the regulation of cell cycle progression. 